\title{
First Record of Fossil Otoliths from the Siwaliks of India
}

\author{
Ram Ratan Singh, K. Milankumar Sharma and Rajeev Patnaik \\ Centre of Advanced Study in Geology \\ Panjab University, Chandigarh-160014, India \\ Email: ramratan84@gmail.com
}

\begin{abstract}
This is the first record of fossil otoliths from the Siwalik formation, palaeomagnetically dated to $2 \mathrm{Ma}$, exposed near Village Nadah (Haryana, India). The fossil otoliths belong to the Channidae. One otolith is well preserved and is determined as Channa aff. striata (Bloch), whereas the other two specimens are corroded and can only be classified as Channa. sp. Our findings confirm and extend earlier records of channid fishes from those areas that were based on disarticulated skeleton remains.
\end{abstract}

Keywords: Otoliths, Siwalik, Channidae, India

\section{Introduction}

The inner ear of teleost fishes has three different pairs of mineralized structures, named lapillus, sagitta, and asteriscus, and more generally termed as otoliths (Platt and Popper 1981; Nolf, 1985, 1995). The three otolith pairs are morphologically different, with the sagittae usually being the largest one (Nolf , 1985). Otoliths have importance in hearing by enabling the inner ear to mediate the sense of hearing and balance (Popper et al., 2005). In addition, otoliths play an important role in the identification and taxonomy of fossil fish faunas because they display diagnostic features such as outline, pattern and degree of incision of the sulcus, convexity and concavity of their faces and the thickness, that are genus and species specific (Nolf, 1985; 1995).

Fossil otoliths from India are still insufficiently known. Gowda $(1966,1967)$ was the first who described otoliths from India, the otoliths were found in Upper Cretaceous (Cenomanian) marine sediments. Further, otoliths were reported from marine sediments of Early and Middle Eocene age (Sahni and Saxena, 1982, Middle Eocene of Kutch, Gujarat; Nolf and Bajpai, 1992, Middle Eocene of India and Java; Samant and Bajpai, 2001, Lower Eocene (Cambey Shale); Nolf et al., 2006, Lower Eocene (Ypresian) of Vasatan Lignite Mines, Gujarat). In addition, Rana (1988) reported otoliths from freshwater species from sediments within the Deccan Trapp (Cretaceous-Paleogene Transition) of Rangapur, Hyderabad district, Andhra Pradesh.

However, until to date no otolith records from India are known from Neogene sediments. The objective of this study is to report otoliths from freshwater sediments of the Neogene-Quaternary Siwalik succession of India. 
Open access e-Journal

Earth Science India, eISSN: $0974-8350$

Vol. 7 (II), April, 2014, pp. 49-54

http://www.earthscienceindia.info/

\section{Geology of the Area}

The Pinjor Formation of the Siwalik Group is well exposed in the Nadah area (Fig. 1). Lithologically, Pinjor Formation comprises of alternating sequence of soft and friable, greenish grey, dull colour gravelly sandstone with conglomerate lenses and small lenticular calcrete horizons. Conglomerates are polymodal and polymictic, hard, compacted, matrix supported, calcareous cemented and occasionally containing sand lenses, clay pockets, dominated by sub-angular to sub-rounded clast of quartzite, gneiss and granite and khaki colour hard clay which is calcareous. The sandstones in the lower part of this unit comprise impersistent lenses of cemented conglomerates while their frequency and thickness increases towards the top. The Nadah succession has been dated to 2 Ma based on palaeomagnetic dates, sedimentation rates and fission track ages from tuffaceous mudstones (Tandon and Kumar, 1984; Ranga Rao et al., 1988). The grey mudstone beds that has yielded the otoliths contains ferruginous and calcareous nodules and shows evidence of bioturbation; it is capped by nodular calcium carbonate bands ( $15 \mathrm{~cm}$ thick) indicating a shallow seasonal pool of limited aerial extent (Patnaik, 1995).

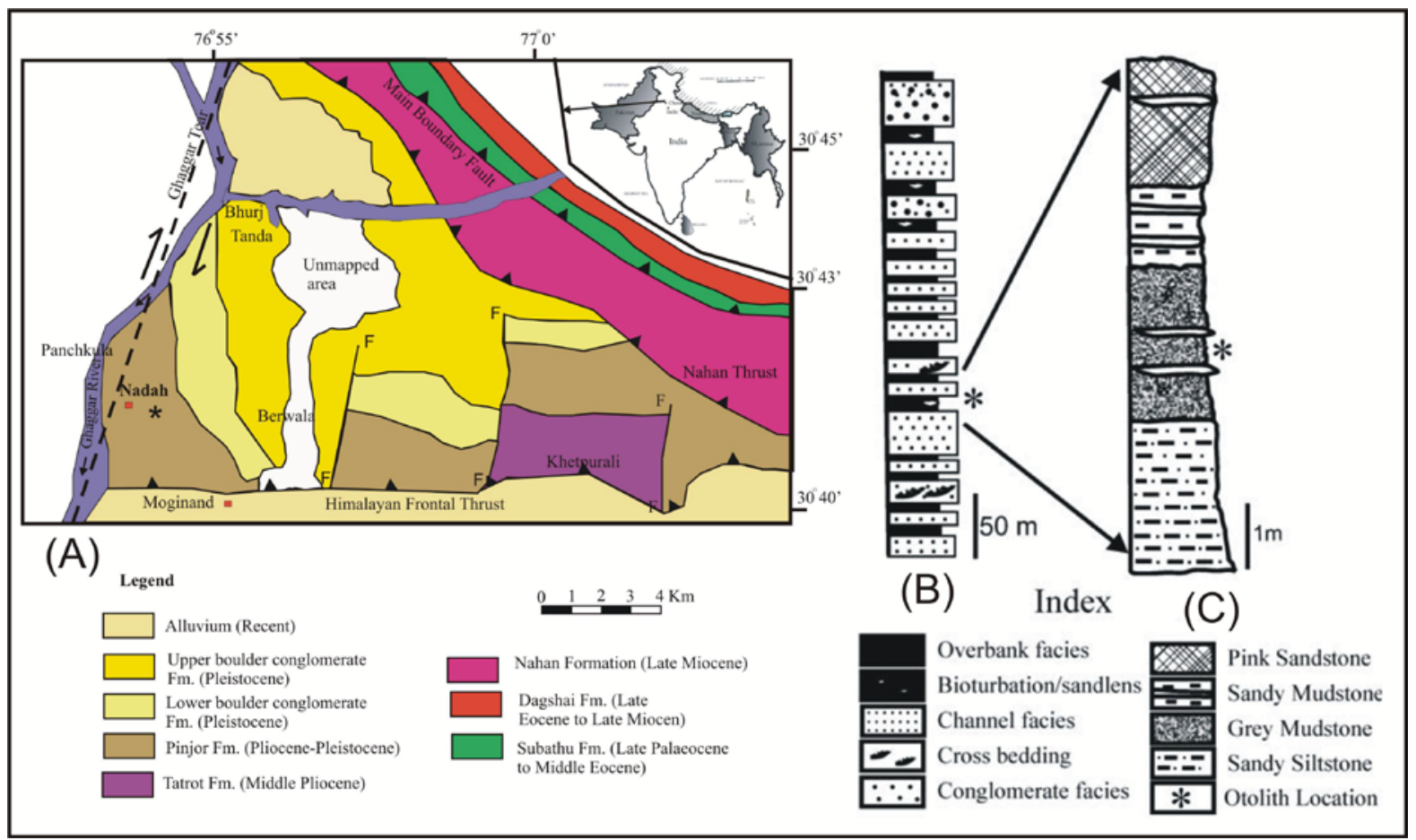

Fig. 1: (A). Location map of the Nadah area with fossil locality in geological map marked by star (modified after Tandon and Kumar, 1984). (B) Litholog showing complete Nadah succession. (C) Detailed litholog of the section showing location of the sample that has yielded the fossil otoliths. 
Open access e-Journal

Earth Science India, eISSN: $0974-8350$

Vol. 7 (II), April, 2014, pp. 49-54

http://www.earthscienceindia.info/

\section{Material and Methods}

The otoliths studied come from the Upper Siwalik deposits that are exposed in the vicinity of Chandigarh near Nadah (N 30 41'20.4”, E 76 54'21.6”). The otoliths have been recovered together with many rodents, fish teeth, micro-gastropods, ostracods, and charophytes from $1500 \mathrm{~kg}$ of sediment by washing and screening. Mostly the sediment was dissolved in water but for some hard calcareous sediment, kerosene was also used. The dissolved material was screened by different mesh sizes down to120 $\mathrm{mm}$, the remains in the mesh were dried and finally microfossils and otoliths were picked. The terminology used for the otolith description follows Nolf (1985) and is shown in Fig. 2a. For the determination of the otoliths, we used Nolf (1985), Gaudant and Reichenbacher (1998) and Krainara and Wunnitikul (2004) for comparison with recent species and Jost et al. (2006) for comparison with fossil species.

\section{Systematic Palaeontology}

The described otoliths are housed in the repository of the Centre of Advanced Study in Geology, Panjab University, Chandigarh.

Class OSTEICHTHYES Huxley, 1880

Subclass ACTINOPTERYGII Klein, 1885

Infraclass TELEOSTEI Mueller, 1848

Superorder ACANTHOPTERYGII, Gouan, 1970

Order CHANNIFORMES Greenwood et al. 1966

Family CHANNIDAE (Berg, 1940)

Genus Channa Scopoli, 1777

Channa aff. striata (Bloch,1793)

Fig. 2: b

Horizon and Locality: Grey mudstone of the Pinjor Formation of Upper Siwalik, Nadah, near Chandigarh, India.

Material: 1 right sagitta (no. RRS/VF/PU-10).

Description: The sagittae is 3 to $4 \mathrm{~mm}$ in length and 2 to $3 \mathrm{~mm}$ in width with a thickness of about 1 to $2 \mathrm{~mm}$ at the centre. Outline is oval and elongate in shape, ventral border is thick with highly sculptured knobs and furrows. Dorsal border also sculptured and with a cap like ridge in the middle. Anterior and posterior borders are angular. Inner face is highly convex along the long axis while outer face is somewhat concave. The colliculum are most pronounced at the ostium end. The sulcus is long, wide and curved towards the ventral border; it is closed at the posterior end, but opened interiorly. The incision on the crista superior and crista inferior represents the separation of ostium and cauda, which is additionally indicated by the starting point of the caudal colliculum that is ovate on the posterior side and angular and curved towards the anterior side. The rostrum is angularly curved. The antirostrum and excisura are not clearly recognizable. The outer surface shows distinct growth lines.

Remarks: The otolith shows some similarity to that of Channa striata (see Gaudant and Reichenbacher, 1998: Fig. 2B). The general outline and cauda are similar, but the ostium is 
Open access e-Journal

Earth Science India, eISSN: $0974-8350$

Vol. 7 (II), April, 2014, pp. 49-54

http://www.earthscienceindia.info/

more bent towards the ventral border in the fossil specimen and the central part of the crista superior and crista inferior are horizontal, , whereas in C. striata they are curved. The borders of the fossil otolith are dentate, whereas in $C$. striata only the dorsal border is dentate and the ventral border is smooth. Based on the above mentioned differences to the present-day species the fossil otolith is assigned to Channa aff. striata (Bloch).

Channa sp.

Fig. 2: c, d

Material: Two left sagittae (no. RRS/VF/PU-11, 12)

Description: The otolith of specimen no. RRS/VF/PU-11 (Fig. 2c) is thick, but strongly corroded. It displays a subrounded outline, posterior border is nearly vertical and undulant, and the ostial border is broken. The ventral border is smooth and the dorsal border is weekly dentate. The sulcus has a broad and small ostium and a long curved cauda, terminating just before the postero-ventral border. The bends are most pronounced towards the cauda end. The obtuse angles on the crista superior and crista inferior indicate the separation of ostium and cauda. The rostrum is curved, but broken anteriorly, antirostrum and excisura are not preserved.

The otolith of specimen no. RRS/VF/PU-12 (Fig. 2d) is strongly corroded and the anterodorsal part is not preserved. The sulcus is slightly curved toward the posterior margin and the ostium is straight with an anterior opening. Inner and outer surface are weakly convex, along the long axis.

Remarks: These specimens show some similarity with the otolith of Channa aff. striata described above, but can not be determined on the species level due to their incomplete preservation.

\section{Discussion and Conclusion}

Fossil otoliths of Channidae from the Siwalik deposits of India were not known before and confirm previous reports on the presence of these fishes that were based on skeletal remains from the Middle Siwaliks of Northern India (Lydekker, 1886; Sahni and Khare, 1977) and from the Siwaliks of Pakistan (McClelland, 1844). The rich channid material described by Sahni and Khare (1977), comprising thousands of isolated skeletal remains from the Ladhyani beds (Haritalyangar), Himachal Pradesh, was assigned to three new Channa species, i.e. C. bhimachari (Sahni and Khare (1977), C. gregoryi (Sahni and Khare (1977), and C. romeri (Sahni and Khare, 1977). In addition, fossils of Channidae were mentioned from the Pleistocene of Java (Boesman, 1949).

At present, the genus Channa (Ophiocephalus) is represented by four species in the Indian subcontinent: C. punctatus (Bloch, 1793), C. marulius (F. Hamilton, 1822), C. gachuna (F. Hamilton, 1822), and C. striatus (Bloch, 1793). They live in the rivers of the Indo-Gangetic plain and also in the peninsular Indian rivers and in the rivers of the south and southeastern countries, such as Burma, Ceylon, Malaya, Thailand, China, Islands of the East Indian Archipelago (Sahni and Khare, 1977). The otoliths from the Pinjor Formation of the Siwalik group extend the range of fossil Channidae from the Neogene up to the Pleistocene, 
Open access e-Journal

Earth Science India, eISSN: $0974-8350$

Vol. 7 (II), April, 2014, pp. 49-54

http://www.earthscienceindia.info/

but more studies are necessary to understand the relation between the fossil and the presentday species.

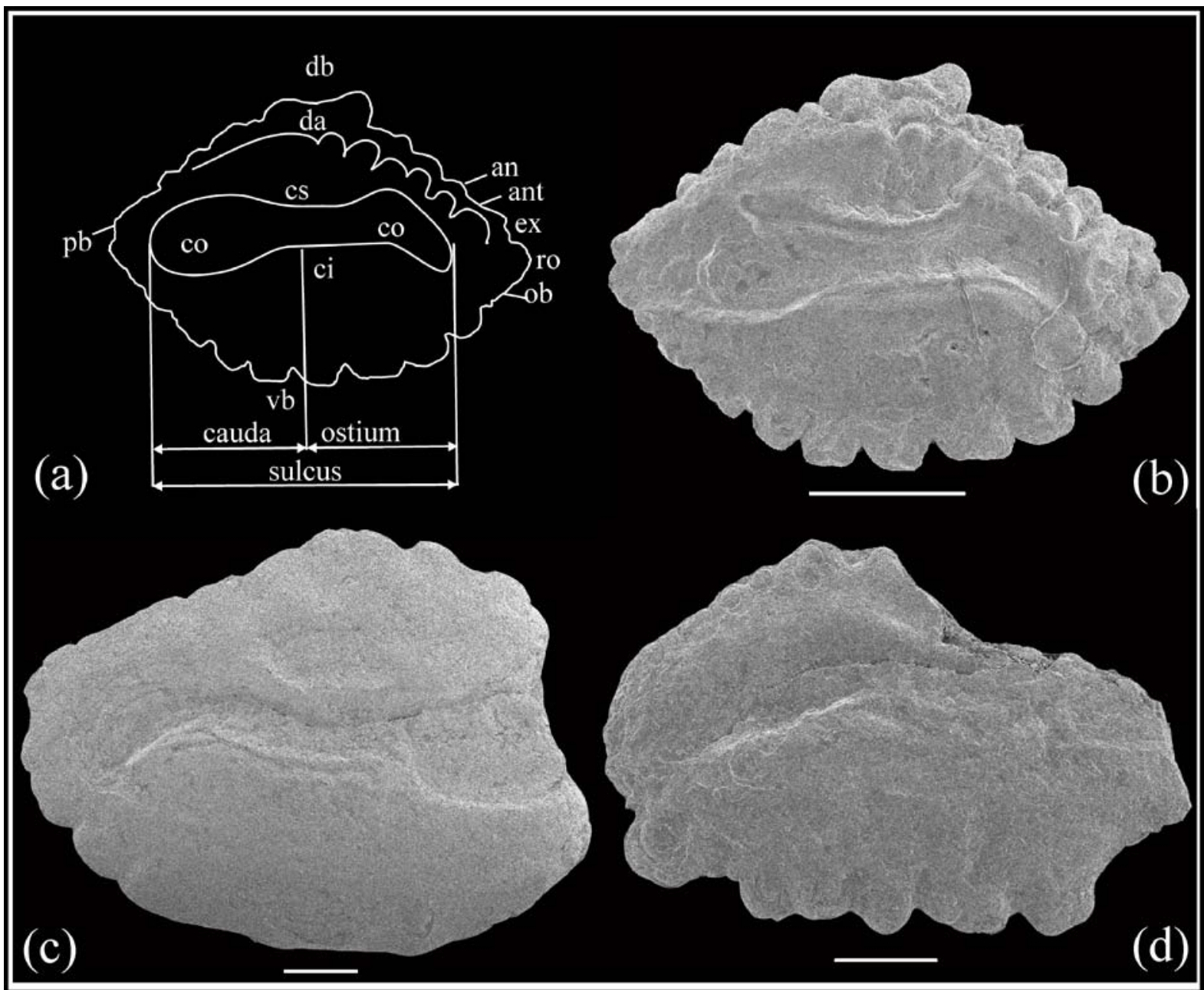

Fig. 2: (a) Morphological nomenclature of the inner face of the otolith (sagittae). (b) Inner face of the right sagitta of Channa aff. striata. (c-d) Inner face of left sagittae of Channa sp. Scale bar: $500 \mu \mathrm{m}$.

Abbreviations used: an- anterior part; ant- anterostrum; ex- excisura; ro- rostrum; ob-ostial border; db- distal border; pb- posterior border; vb- Ventral border; cs- crista superior; cicrista inferior; co-colliculum.

Acknowledgments: We are thankful to Prof. Bettina Reichenbacher for her kind help in constructing review and editing the manuscript preparation at every stage without whom this paper couldn't be at present stage. We are thankful to Prof. Ashok Sahni for several critical suggestions in the improvements of the quality of this work. The financial support provided by DST, New Delhi (No.-SR/S4/ES-171/2005) is thankfully acknowledged. 
Open access e-Journal

Earth Science India, eISSN: $0974-8350$

Vol. 7 (II), April, 2014, pp. 49-54

http://www.earthscienceindia.info/

\section{Reference}

Boesman, M. (1949) On Pleistocene remains of Ophiocephalus from Java. Zoolgische mededelingen. v.30, pp.83-94.

Gaudant, J. and Reichenbacher, B. (1998) Première découverte d'un squelette de Channidae (Poisson téléostéen) dans le Miocène inférieur d'Illerkirchberg, près d'Ulm (Wurtemberg, Allemagne).- Paläont. Zeitschrift, v.72(3/4), pp. 383-388.

Gowda, S.S. (1966) The first fossil otolith from India. Bull. Geol. Soc. India. v.4, pp.15-17.

Gowda, S.S. (1967) On a new fossil fish known from an otolith from the South India Cenomanian. Jour. Geol. Soc. India. v.8, pp.119-129.

Jost, J., Kälin, D., Schulz-Mirbach, T. and Reichenbacher, B. (2006) Late Early Miocene lake deposits near Mauensee, central Switzerland: fish fauna (otoliths, teeth), accompanying biota and palaeoecology. Eclogae Geologica helvetiae, v.99, pp.309-326.

Krainara, P. and Wunnitikul, P. (2004) Sagitta morphology of Channa spp. from Southern area of Thailand. Jour. Microscopy of Thailand. v.18(1), pp.61-62.

Lydekker, R. (1886) The Indian Tertiary and Post tertiary Vertebrata Tertiary fishes. Palaeontologica Indica, Series 10, v.3(1-8), 264p.

Nolf, D. (1985) Otolithi piscium. In: H. P. Schultze (ed.) Handbook of paleoichthyology, v.10. Gustav Fischer, Stuttgart, 145p.

Nolf, D. (1995) Studies on fossil otoliths-the state of the art. In: D. Secor, J. M. Dean, and S. Campana (eds.) Recent developments in fish otolith research. University of South Carolina Press, Columbia. pp. 513-544.

Nolf, D. and Bajpai, S. (1992) Marine Middle Eocene fish otoliths from India and Java. Bulletin de l' Institut royal des Science naturelles de Belgiques, Sciences de la terre, v.2, pp.175-221.

Nolf, D., Rana, R.S. and Singh, Hukum (2006) Fish otoliths from Ypresian (early Eocene) of Vastan, Gujrat, India. Bulletin de l’Institute royal des sciences naturelles de Belgiques, Sciences de la Terra,v.76, pp.105118.

Patnaik, R. (1995) Micromammal-based palaeoenvironment of Upper Siwaliks exposed near Village Saketi, H.P. Jour. Geol. Soc. India. v.46, pp.429-437.

Platt, C. and Popper, A. N. (1981) Fine structure and function of the ear. In: W. N. Tavolga, A. N. Popper and R. N. Fay (eds.) Hearing and communication in fishes. Springer, New York. pp. 3-36

Popper, A.N., Ramcharitar, J.U. and Champana, S.E. (2005) Why otoliths? Insight from inner ear physiology and fisheries biology. Marine \& Fresh water Research, v.56, pp.497-504.

Rana, R.S. (1988) Freshwater fish otoliths from the Deccan Trap associated sedimentary (Cetaceous-Tertiary Transition) Beds of Rangapur, Hyderabad district, Andhra Pradesh. Geobios, v.21: pp.465-493.

Ranga Rao, A., Agarwal, R.P., Shasma, U.N., Bhalla, M.S. and Nanda, A.C. (1988) Magnetic polarity stratigraphy and vertebrate paleontology of the Upper Siwalik subgroup of Jammu Hills, India. Jour. Geol. Soc. India, v.31(4), pp. 361-385.

Sahni A. and Sexana, R.K. (1982) Middle Eocene otoliths from Jhadwa, Southern Kutch. Jour. Palaeont. Soc. India, v.27, pp.64-67.

Sahni, A. and Khare, S.K. (1977) A middle Siwalik fish fauna from Ladhyani (Haritalyangar), Himachal Pradesh. Biolo. Mem. v.2(1-2), pp.187-221.

Samant, B. and Bajpai, S. (2001) Fish otoliths from the sub-surface Cambay shale (Lower Eocene), Rurat Lignite field, India. Curr. Sci., v.81(7), pp.758-759.

Tandon, S.K. and Kumar, R. (1984) Discovery of tuffeceous mudstones in the Pinjor Formation of Panjab subHimalaya, India. Curr. Sci., v.53(18), pp. 982-984.

(Received: 22.09.2011; Accepted: 15.03.2014) 